\title{
化学情報協会におけるインフォプロ育成
}

\section{Education of infopros at JAICI}

原修 ${ }^{1}$

\section{HARA Osamu ${ }^{1}$}

1 一般社団法人化学情報協会（干113-0021 東京都文京区本駒込6-25-4 中居ビル）

1 Japan Association for International Chemical Information (Nakai Bldg. 6-25-4 Honkomagome Bunkyo-ku, Tokyo 113-0021)

原稿受理 (2013-11-07)

情報管理５6(10), 669-676, doi: 10.1241/johokanri.56.669 (http://dx.doi.org/10.1241/johokanri.56.669)

著者抄録

化学情報協会（JAICI）は，30 年以上にわたるSTN，SciFinderの販売・ユーザーサポート，CA の抄録・索引作成業務 に加えて特許庁登録調査機関として特許審査のための先行技術調査をほぼ 10 年間行っており，多くのインフォプロを 育成してきた。近年，特許を主体とする一般向け調査・検索サービスを開始するにあたり総合的なインフォプロを育 てることになった。その背景と過程を化学および化学関連分野のインフォプロ育成の一例として紹介する。

キーワード

CAS，STN，化学情報，特許情報、情報検索，化学特許，代行検索，インフォプロ，インフォプロ育成，教育プログラム

1.はじめに

1960年代後半，当時の爆発的な情報量増大に対 処するため，米国化学会 (ACS: American Chemical Society）は日本を含む先進国（イギリス，フランス， ドイツ）に対して，抄録誌Chemical Abstracts（CA） の情報入力に関する協力要請を行った。1968年に日 本化学会がACSから協力要請を受け，当時すでに設立 されていた旧日本科学技術情報センター（JICST，現 (独) 科学技術振興機構の情報サービス部門) とは別 に，分野ごとに専門情報センターを設立しようとい う当時の機運も反映して，1971年に化学情報協議会 が任意団体として設立された。その後1975年に，当 時の文部省，総理府（科学技術庁）の認可を受け，
社団法人組織となり名称を化学情報協会 $(J \mathrm{AICl})$ に 改めた。近年実施された公益法人制度改革に基づき， 2011年に一般社団法人に移行した。

当協会のミッションは，「化学情報を通して日本の， そして世界の科学技術情報の発展に貢献する」こと であり，その実現のために現在表1の事業を，それぞ れの緊密な協力関係を保ちながら推進している。各 事業の協力関係については図1をご覧いただきたい。

\section{2.インフォプロ育成の経緯}

当協会は，STNの前身であるCAS Onlineから数えて 30年以上にわたりSTNのユーザーサポート業務を行っ てきた。現在，相当数の情報検索応用能力試験 2 級合 


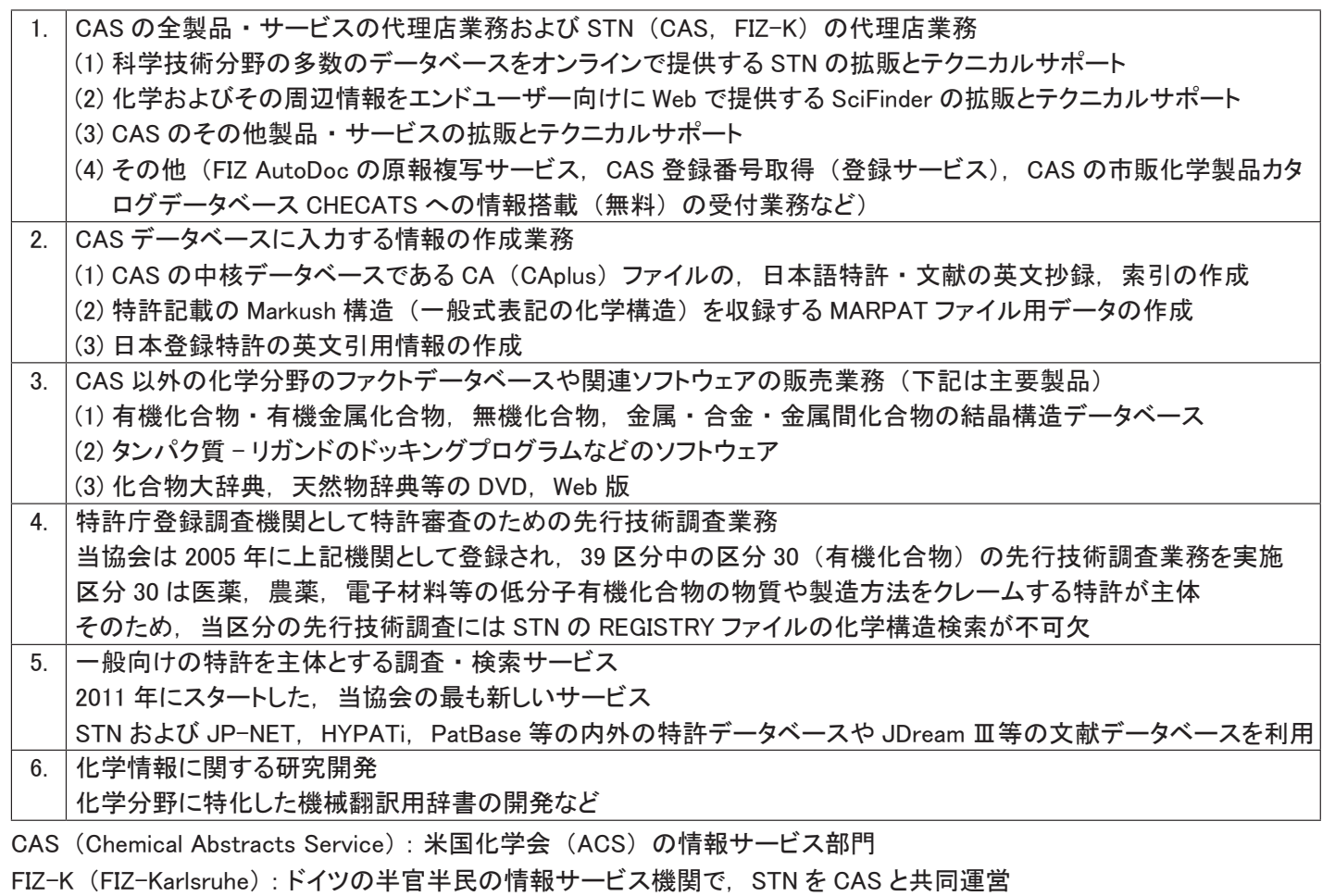

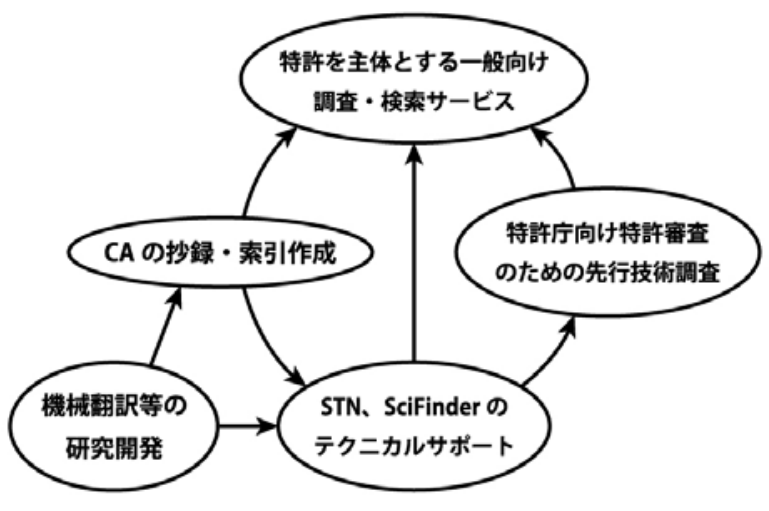

図1 化学情報協会の主要事業間の協力関係

格者，数名の1級合格者もおり，STNやSciFinderのテ ク二カルサポート業務（表1-1.）を担当する多くのイ ンフォプロを抱えている。また，特許庁向け調査業 務（表1-4.）のために，多くの特許調査のプロも育成 した。一方，化学分野の調査に不可欠なCA（または CAplus）ファイルを使う際には，この索引に精通し ていることが大きな強みになるが，当協会では30年 以上にわたりCAの英文抄録・索引作成業務（表1-2.） を行っており，多数のCA索引のプロが育っている。
以上の状況のもと，2011年に表1-5.の新規サービス を開始するにあたり，特許を主体に化学を中心とす る広い分野の調査依頼に応えられる総合的な能力を もつインフォプロの育成が必要になつた。

\section{3. 化学分野のインフォプロの必要条件}

新規サービスを担当するスタッフに求められる条 件を確認するために，特許調査を中核とする化学分 野の総合的なインフォプロに必須と思われる条件を 表2にまとめた。なお，企業の特許調査担当者にとつ て一般的に必要とされる知識とスキルについてはほ かの文献1），2）を参照されたい。

多くのメーカーでは理系出身ではないインフォプ 口が活躍されているが，当協会では実務を通して化 学の基礎的知識を身につけることは困難であるため， 化学系出身者であることを第1の条件とした。なお， 一般的にインフォプロに求められる資質（緻密さ， 臨機応変能力，コミュニケーション能力など）につ 
表2 化学分野のインフォプロの必要条件

\begin{tabular}{|c|c|}
\hline 1. & $\begin{array}{l}\text { 化学および化学関連分野のバックグラウンドを有すること } \\
\text { (有機化学関連分野が望ましい) }\end{array}$ \\
\hline 2. & 化学を中心とする幅広い科学技術知識を有すること \\
\hline 3. & STN のほぼすべてのファイル（データベース）を使いこなせること \\
\hline 4. & STN のあらゆる機能および料金体系に精通していること \\
\hline 5. & 特にCA ファイルの索引に精通していること \\
\hline 6. & 特許調査に必要な範囲の特許法に精通していること \\
\hline 7. & $\begin{array}{l}\text { 日本特許の調査に不可欠な } \mathrm{FI}, \mathrm{F}-\text { ターム, および各種特許 } \\
\text { 分類に精通していること }\end{array}$ \\
\hline 8. & さまざまなタイプの特許調査に実戦的に対応できること \\
\hline 9. & 特許が読め, 特許・論文のスクリーニングができること \\
\hline
\end{tabular}

いては，本稿では触れないことにする。

表2の条件のほとんどは，表1-1.,2.,4.の業務経験を 通して獲得できることから，これら各業務のプロの ノウハウを統合することによって新規サービスを実 現できると考えた。

そのため，これらを担当する部署から適切なスタッ フを集め，お互いのノウハウ共有に努めるとともに， 後述のとおり不足するスキル・知識については準備 期間内に手厚く実践的なトレーニングを実施するこ とによって新規サービスを開始することができた。 本稿では，これら表1-1., 2., 4.の3業務の内容と新人卜 レーニング，ならびに新規サービス開始に向けて実 施した追加のトレーニングを紹介する。

\section{STNのテクニカルサポート業務}

化学および化学関連分野の調査は，CAS (Chemical Abstracts Service）のデータベース（DB）を抜きに語 ることはできない。そのため，新規サービスを担当 するスタッフは，CASのDBとその他の多数の科学技 術分野のDBを強力な検索機能とともに提供するSTN の機能と各DBに精通し，かつ料金体系を十分理解し ていることが不可欠である。

STNが提供する主要DBを分野別に表了にまとめた。 化学分野に限っても，特許を含む文献検索，化学構 造検索と辞書検索（化学構造以外のデータ（名称， 分子式など）を使った検索）を駆使する化合物検索， 有機化学反応検索，化学物質の物性 - 毒性 ·法規制 検索，タンパク質・核酸の配列検索，特許のMarkush 構造検索などがあり，これらを使いこなすためには それぞれに特有の検索方法を習得しなければならな い。また，化学とは表裏一体の関係にある医薬，農薬， 食品，化粧品などの分野のDBの検索にも精通する必 要がある。

表3 STNが提供する主要データベース

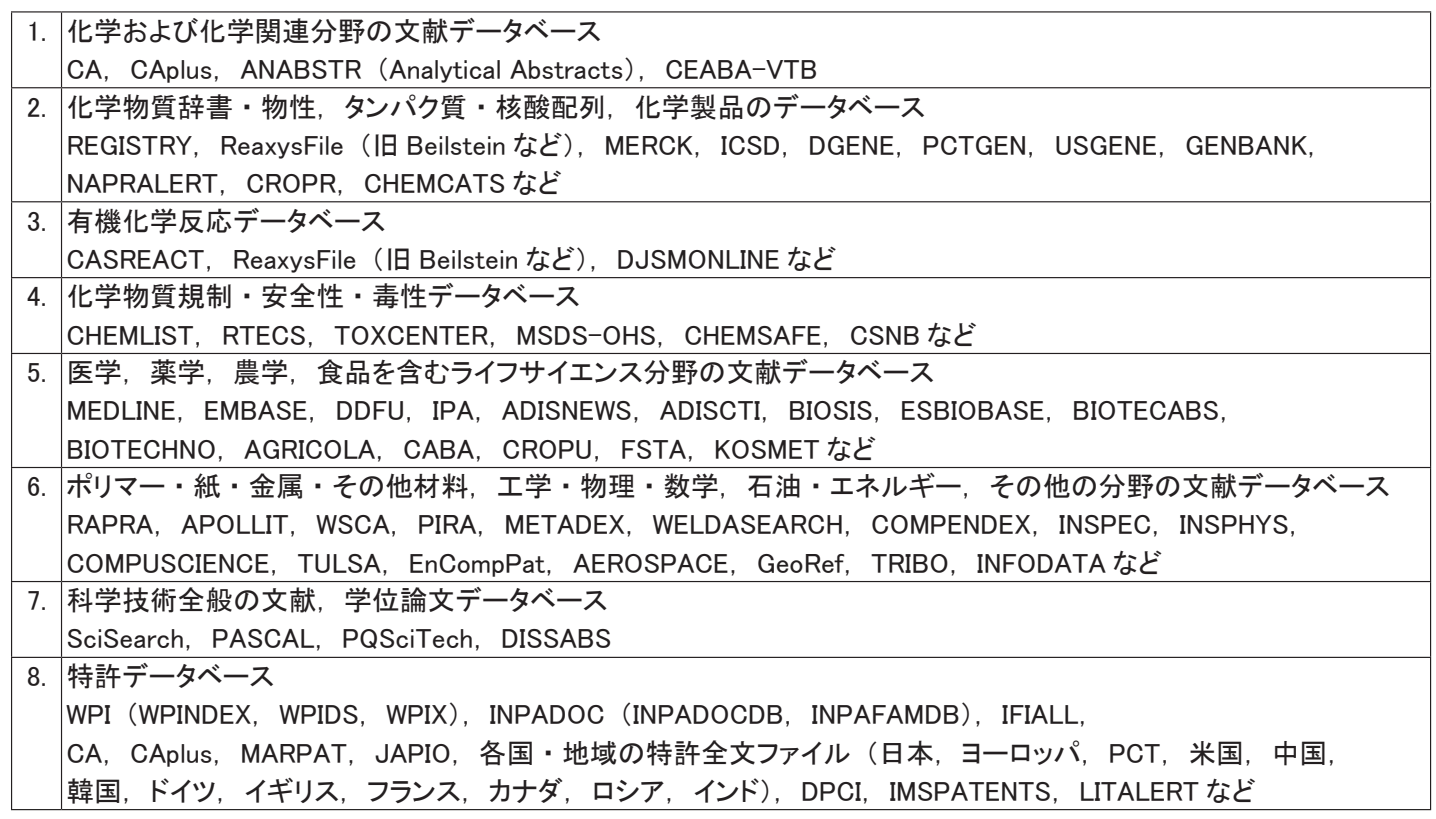




\section{1 業務内容}

STNのテクニカルサポート業務は，情報事業部テク 二カルグループが担当している。同グループの主要 業務は表4のとおりである。現在，東京・大阪で10種 類を超えるSTN講習会を開催するほか，特許や医薬な どの大規模セミナー，および夏冬に開催する各種リ フレッシュ・おさらいセミナー，さらにはさまざま なテーマのインターネットセミナーを定期的に開催 している。また，近年ユーザーの要望に合わせた出 張講習会も増加している。これらの講習会やセミナー を開催するためには，講師業務だけではなくテキス 卜作成にも膨大なエネルギ一を要するが，これらの すべてを当協会スタッフが独自に作成している。

以上のほか，各種ポケットガイド，STN検索カード， STNデータベースカタログ，各DBのサマリーシート などの資料作成・改訂なども担当している。

以上の業務を長年担当することによって，表2-2., 3., 4.の条件を十分クリアできるスタッフが育つこと になる。表2-5.の条件である，CAの索引についても ある程度の知識を身につけることができる。また， 近年企業におけるSTNの利用が知的財産部にシフトし ていることから，表2-6., 7.の条件である特許調査に 必要な知識を習得する必要性が以前にも増して強く なっている。

\section{2 新人トレーニング}

新人がテクニカルグループに配属されると，ほぼ4 か月後のSTN講習会講師デビューをターゲットとして 特訓が開始される。まずは，グループリーダーとベ テランスタッフによる，当グループの業務の概要説

表4＼cjkstart情報事業部テクニカルグループの主要業務

\begin{tabular}{|c|l|}
\hline 1. & STN の各種講習会の講師 \\
\hline 2. & STN, SciFinder のヘルプデスク \\
\hline 3. & STN の各種講習会テキスト作成 \\
\hline 4. & STN ユーザーミーテイグ, 各種セミナーの資料作成 \\
\hline 5. & ポケットガイド等の STN の各種資料の作成 \\
\hline 6. & STNews, STNewsline 等の記事執筆と発行 \\
\hline 7. & ホームページ経由の STN の各種広報 \\
\hline
\end{tabular}

明を受けつつ表5記載のトレーニングを開始する。そ の後，講習会のレパートリーを増やしつつテキスト の改訂業務も行い，またヘルプデスクでの幅広い質 問に答えることによってSTNのプロに育っていくこと になる。

その後以下の業務を通したOJTによって，スキルと 知識の幅を広げることになる。

（1）日本知的財産協会（JIPA）や同業他社の各種セ三 ナーに順次出席

（2）情報科学技術協会 (INFOSTA) 主催の各種セミナー に交替で出席

（3）同協会の日本オンライン情報検索ユーザ会 （OUG）の各種分科会への参加

（4）下記の外部団体の活動に会員としてあるいはオブ ザーバーとして参加

・日本PLASDOC協議会およびPLASDOCオンライン 研究会

・日本FARMDOC協議会

・日本アグケム情報協議会

・日本製薬情報協議会

- Patent Information Users Group（PIUG，米国）

（5）講習会・セミナ一などのテキスト作成・改訂と講師 ・各種STN講習会

・各種セミナー（特許DBセミナ一，医薬DBセミ ナー, リフレッシュセミナー，おさらいセミナー など）

・インターネットセミナー

表5＼cjkstart情報事業部テクニカルグループの新人トレーニングの概要

\begin{tabular}{|c|c|}
\hline 1. & $\begin{array}{l}\text { 講習会関係 } \\
\cdot \text { STN ユーザー向け各種講習会に出席 } \\
\cdot \text { ·講師をするつもりで徹底的に自習 } \\
\cdot \text { 講習会講師スタート【4 か月目〜】 }\end{array}$ \\
\hline 2. & $\begin{array}{l}\text { 資料作成関係 } \\
\text { · STN サマリーシートの改訂版作成（翻訳） } \\
\text { ·各種資料のファイリング }\end{array}$ \\
\hline 3. & $\begin{array}{l}\text { ヘルプデスク関係 } \\
・ \text { メールで受けた質問への回答（下書き）作成【3 か月目〜】 } \\
\text { 先輩スタッフによるチェック後に送信 } \\
\text { ·電話による質問への回答【4か月 目〜】 } \\
\text { 先輩スタッフからの助けを借りながら回答 } \\
\end{array}$ \\
\hline
\end{tabular}


・STNユーザーミーティング

(6) STNews，STNewslineなどの記事執筆

（7）部内各種勉強会の実施

\section{CAの抄録・索引作成業務}

1907年に発刊された抄録誌Chemical Abstracts （CA）は，2009年に百年を超える紙媒体としての歴 史に幕を閉じたが，まったく同じ情報を提供するSTN のCAファイル，さらに多くのプラスアルファの情報 を収録するCAplusファイルが，STN，SciFinderで提 供されている。

当協会では，1982年から日本語特許・文献のCA抄 録・索引の作成業務を行っており，CA収録全分野（バ イ才，有機化学，高分子，応用化学，物理・無機・ 分析化学）の広い範囲をカバーしている。2012年か らは，STNのMARPATファイル用の，日本語特許の Markush構造作成も開始した。

\section{1 業務内容}

CAの抄録は，原報を読むべきかどうかの判断材料 を提供することを目的としている。当業務担当者（以 下アナリスト）は原報を熟読し，十分な内容理解の もとに抄録に盛り込むべき情報を判断し，簡潔な英 文で抄録を作成することが要求される。そのため， 化学の幅広い知識と英語能力が必要とされる。

CAの索引は，化学物質索引とそれ以外の索引（科 学技術用語からなる統制語による索引，物質の総称 名を含む）の2種類があり，CAに索引された全化学物 質がREGISTRYファイルに収録されている。CAではあ らかじめ技術分野別に索引方針が詳細に定められて おり，アナリストはそれにしたがって索引作成作業 を行う。

CAファイルの検索では，一般に統制語と非統制語 の両方を使うケースがほとんどではあるが，適切な 統制語を使わずに検索すると多くの検索漏れとノイ ズが発生することになる。CAの索引を熟知したアナ
リスト経験者が，適切な統制語と非統制語を組み合 わせることによって，漏れのない効率的な検索が可 能となる。また，後述のとおり新人アナリストは最 初に高分子分野を担当することになっているため， REGISTRYファイルの検索でもつとも難しいとされる ポリマー検索に強いスタッフが育つことにもなる。

高分子分野を3年程度経験したのち他分野を担当 するのが一般的であり，キャリアを積むにつれて幅 広い科学技術知識が身につく。また，日々特許を読 むことになるので，特許調査に不可欠な特許のスク リーニング力も自然に身につくことになる。以上の とおり，CA索引に熟知したアナリストの経験がCA/ REGISTRYファイル検索の極めて強い武器となる。

\section{2 新人トレーニング}

現在，CAの有機化学分野の特許，文献は多くない が，アナリストのバックグラウンドとして有機化学 の知識を有することを採用条件にしている。そのよ うな条件に合致した新人に対して，おおむね表6のス ケジュールにしたがって新人トレーニングを実施す る。最初にポリマー分野の特許を対象とするのは，ポ リマー分野の索引が他分野に比べて難易度が高いこ と，また他分野でもポリマーは頻繁に使われるため， 将来他分野を担当する場合にも役立つためである。

ほぼ10か月でCASアナリストの承認を得て，独り 立ちすることになる。ただし，抄録・索引作成のプ ロとしてのトレーニングはここからが始まりで，質 量ともに一人前のアナリストになるためには3年程度

表6 アナリストの新人トレーニングの概要

\begin{tabular}{|c|c|}
\hline 1. & $\begin{array}{l}1 \text { か月目 : } 2 \text { か月目からの抄録・索引作成業務開始の準備 } \\
\text { - STN 基礎的講習会に出席 } \\
\text { - 同業務を行うためのCAS のツール類に慣れる } \\
\text { - CA 抄録・索引のマニュアルを読んで基本方針を理解する } \\
\text { - 先輩アナリストの索引入カの補助業務を行う }\end{array}$ \\
\hline 2. & $\begin{array}{l}2 \sim 7 \text { か月目: 抄録・索引作成の実務訓練 } \\
\cdot \text { ポリマー分野の特許の抄録・索引作成 } \\
\text { 当協会の先輩アナリストが全件チェックし } 1 \text { 対 } 1 \text { で指導 }\end{array}$ \\
\hline 3. & $\begin{array}{l}8 \sim 10 \text { か月目: } \\
\text { · ポリマー分野の特許の抄録・索引作成 } \\
\text { CAS アナリストによる全件チェック }\end{array}$ \\
\hline
\end{tabular}


を要する。

その後は，英語のスキルをあげつつ担当分野を広 げ，新しい技術を理解し，CASからのフィードバック に対応し，また部内勉強会の講師役などを務めなが ら，ベテランアナリストに成長していく。その過程で， 中堅アナリストはトレーナー役として新人アナリス 卜の指導を行い，実務上は勿論精神的にも大きく成 長することになる。また，不定期ながら特定分野の CASでのトレーニングや当協会で行うCASアナリスト による実践的なトレーニングなども行う。

\section{6. 特許庁向け調査業務}

当協会では，以上紹介した，30年以上にわたる STNの提供とCAファイルの抄録・索引作成業務によ り，STNの検索とCA索引に強い多くのプロが育って いる。一方，これらの経験に特許調査のノウハウが 加われば，総合的なインフォプロが育つことになり， 特許調査を主体とする一般向け調査・検索サービス の体制が整うことになる。

2004年の法改正によって，特許庁の新しい登録調 査機関制度が始まり，従来の指定調査機関以外でも
特許審査のための先行技術調査業務が行えるように なった。当時の特許庁技監からの呼び掛けもあり， 当協会はSTNのREGISTRY，CA/CAplusファイルを使つ た化学構造検索を必須とする有機化合物分野（区分 30，表1-4.を参照）の調査を行う登録調査機関として 参入した。

登録調査機関として承認されるためには，INPIT （(独）工業所有権情報・研修館）の調査業務実施者育 成研修に出席し，修了認定された調査業務実施者を1 分野（区分）当たり10名以上そろえることが必須で ある。2005年早々に開催された第1回研修で，当協会 は最低限の10名を修了させることができ，同年4月か ら同調査業務を開始した。その後も調査業務実施者 を増やし，現在は20名を超えるスタッフが調査業務 を行っている。

現在，調査業務実施者として先行技術調査の実務 を開始するまでに5か月間のトレーニングを行ってお り，表7のスケジュールにしたがって実施される。な お，区分30の調査業務実施者を目指す場合は，INPIT の研修受講前にSTN検索に習熟していることが条件で ある。

当先行技術調査を数年間経験することによって，

表7 特許庁先行技術調査のための新人トレーニングの概要

\begin{tabular}{|c|c|}
\hline 1. & $\begin{array}{l}1 \text { か月目 : STN コマンド, REGISTRY, CAplus ファイルの使い方習得 } \\
\text { · STN のコマンド, REGISTRY (化学構造検索), CAplus ファイル講習会に出席 } \\
\text { · テキストの練習問題による化学構造検索演習と講師によるフィードバック } \\
\text { ·簡単なクレームの特許を用いた化合物の新規性検索練習と講師によるフィードバック }\end{array}$ \\
\hline 2. & $\begin{array}{l}2 \text { か月目：検索の実践とExcel を使った報告書作成練習 } \\
\text { ·実際の特許を課題とした先行技術調査を行い, Excelによる報告書を作成 } \\
\text { ·報告書に基づくINPIT 研修の面接練習 } \\
\text { ·特許法, FI・F-タームの基礎に関する講義（INPIT 研修の準備程度） }\end{array}$ \\
\hline 3. & 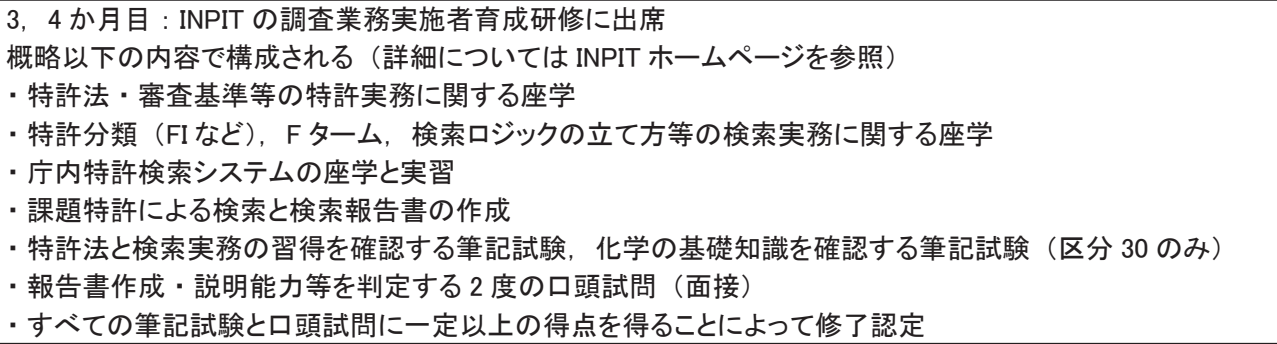 \\
\hline 4. & $\begin{array}{l}5 \text { か月目 : REGISTRY, CAplus 以外の STN ファイルの利用法習得と調査業務を行うための最終トレーニング } \\
\cdot \text { 調査業務に必要な STN の応用機能および構造検索のスクリーン利用法 } \\
\cdot \text { CASREACT (有機化学反応), MARPAT（特許の Markush 構造）ファイル利用法 } \\
\cdot \text { ·医学・薬学分野のファイル (MEDLINE, EMBASE, BIOSIS) 利用法 }\end{array}$ \\
\hline
\end{tabular}


先行技術調查のプロが育つことになる。当業務を通 して，REGISTRY，CAファイルを核とするSTN検索， FlやF-タームおよび特許のテキスト全文を使った日本 特許の検索，特許のスクリーニング，特許の新規性・ 進歩性，審査基準，調查報告書の作成などに精通す ることができる。

\section{7. 総仕上げ：調査のプロを目指して}

表1-5.の調査・検索サービスを開始するにあたり， 表1-1., 2., 4.の担当部署からベテランスタッフを選び 2010年初頭に新サービス開始に向けて準備室を設置 した。あらゆる機会を通じて，お互いが持っている 知識の共有をはかるとともに，さらに以下のトレー ニングを実施した。

\section{1 特許調査に関するトレーニング}

STNのプロおよびCA索引のプロであるスタッフは， まずは特許調査の基礎をかためる機会として，INPIT の合意を得て前記の調査業務実施者育成研修に出席 し，修了認定を受けた。CA索引のプロについては， STNに関する知識が限定的であるため，表7の研修出 席前後のSTNのトレーニングも実施した。

\section{2 全スタッフに対する仕上げのトレーニング}

以上のトレーニングの後に，全スタッフに対して 以下のトレーニングを実施した。

（1）日本特許DB，および世界特許DB利用のためのト レーニング

特許調査には日本特許D Bの検索と特許公報の入手 が不可欠であるため，早々に日本特許DBサービス 会社の選定を行い，契約した。DBサービス会社ス タッフによる社内セミナーを実施するとともに， 後記のとおりこれを利用した実践的トレーニング も実施した。また，その後世界特許のDBサービス の契約も行い，同様のトレーニングを実施した。

\section{（2）文献DB検索のトレーニング}

特許調査においても，侵害防止調査以外の先行技 術調査，無効化資料調査，特許性調査，技術動向 調査では，非特許文献の調査も必要となる。その ため，JDream II（現在はIII）などの主に文献調査 を主体にしたDBサービスについても，各種セミナー に出席しレパートリーを広げるべくトレーニング を行った。

\section{（3）各種特許調査セミナーへの出席}

JIPAやINFOSTAおよび特許DBサービス会社が主催 する特許調査セミナーに出席した。基礎的なもの から斯界の著名人を講師とするものまでさまざま なセミナーが開催されており，特許調査の基本か らより高度なノウハウまでを貪欲に吸収すること ができた。

（4）内部セミナー

企業から受けるさまざまな種類の特許調査依頼（先 行技術調査，特許性調査，侵害防止調査，無効化 資料調査，技術動向調査など）に対応するためには， それぞれに応じた実戦的な調査能力を身につける 必要がある。そのため，特許調査に精通した某化 学メ一カーOBに講師役をお願いし，当協会内でセ ミナーを実施した。当セミナーは，ほぼ6か月間， 隔週程度のペースで行い，座学とともに例題を用 いた日本特許DBを利用した検索結果を持ち寄って 検討し，各スタッフが持つノウハウを共有すると ともに実戦的な調査能力を育成した。当セミナー によって，上記の特許調査の種類に応じた特徵を 理解し，検索の際に留意すべき事項を身につける ことができた。

以上の準備を終えたのち，外部より豊富な医薬開 発経験を有し，かつ医薬DBに詳しいマネージャーを 迎えて2011年春より，特許調査を主体とする新規調 査・検索サービスを開始することができた。

その後、メーカーでの調査と当協会での特許庁向 け調査業務経験を有し，かつほかの調査会社での特 許調査業務も経験したスタッフが新たに加わり，よ 
り強力なチームに育ちつつある。受注した案件を内 容に応じて複数のスタッフが共同で担当することに よって，各スタッフが持つ知識と経験のシナジー効 果を発揮しつつ，それらの共有化を進めている。ス タートしたばかりの部署にとつて各スタッフの知識 の共有化は重要な課題であるため，受注量の波に耐 えながら常時意識して共有化に努めている。今後は， メ一カーでの特許調査経験者も増やしながら当協会 の主要事業に育てていきたいと考えている。

\section{8. おわりに}

長年愛読していた，本誌のリレーエッセー「イン フォプロってなんだ?」が残念ながら2012年をもっ て終了した。さまざまな分野のインフォプロによる
エッセーおよび当シリーズ終了に際して実施された 座談会3) から，多様なバックグラウンドを有する方々 が多様なトレーニングと経験を通して立派なイン フォプロに成長された様子がよくわかる。

拙文をお読みいただいておわかりの通り，当協会 のインフォプロ育成環境は，世の中の大部分を占め るメーカーのそれとは大きく異なる。おそらく，昨 今の状況から，メーカーのインフォプロの業務とし て，研究者・技術者が自ら行うエンドユーザー検索 の体制整備や指導も大きな比重を占めていると思わ れる。

しかしながら，インフォプロに要求される条件は， メ一カーでも当協会でも大きな違いはないと思われ る。拙文がいささかなりとも皆様の自社におけるイ ンフォプロ育成のご参考になれば幸いである。

\section{参考文献}

1) 臼井裕一. 特許情報教育の現状と課題: 特許調査の担い手とその教育はいかにあるべきか. 情報の科学と技 術. 2012, vol. 62, no. 4, p. 148-152.

2）長澤洋. グローバル化時代の知財情報＼cjkstart必要とされる情報と人材. 情報管理. 2012，vol. 55，no. 5, p. 339346.

3）鍛治恭子, 山崎登和子, 渡辺喜代美, 松谷貴己. インフォプロの成長点 リレーエッセー「インフォプロっ てなんだ?」終了にあたり.情報管理. 2013, vol. 55, no. 10, p. 712-721.

\section{Author Abstract}

JAICI (Japan Association for International Chemical Information) has been endeavoring to raise many infopros through marketing and user support of STN/SciFinder and preparing CA abstracts and indexes for more than 30 years and prior arts search for patent examination on behalf of Japan Patent Office for almost 10 years. Recently, JAICI has started a new business, search service for focusing on patent search for private sectors, which is our new challenge for raising all-round infopros. Backgrounds and processes are described as an example of infopro-education in chemistry and its related fields.

Key words

CAS, STN, chemical information, patent information, information retrieval, chemical patent, information broker, infopro, infopro education, education program 